DOI: $10.21802 / \operatorname{artm} .2020 .3 .15 .174$.

УДК 616.36-003.4-089

\title{
ХІРУРГІЧНЕ ЛІКУВАННЯ НЕПАРАЗИТАРНИХ КІСТ ПЕЧІНКИ
}

\author{
В.О. Шапринський, О.О. Воровський, О.А. Камінський, Я.М. Пашинський, Ю.А. Миронишен
}

Вінницький нащіональний медичний університет ім. М. І. Пирогова, кафедра хірургії №1

з курсом урології, м. Вінниия, Украӥна,

ORCID ID: 0000-0002-3890-6217, ORCID ID: 0000-0002-8933-3965,

ORCID ID: 0000-0002-7753-6933, ORCID ID: 0000-0002-3001-9955,

ORCID ID: 0000-0001-8837-2025,

e-mail:surgery1@vnmu.edu.ua

Резюме. Мета дослідження: покращити результати хірургічного лікування непаразитарних кіст печінки за рахунок розробки та удосконалення методів оперативного втручання.

Матеріал та методи. Прооперовано 102 хворих: 88 (86,3 \%) - непаразитарні кісти печінки, 14 (13,7 \%) - полікістоз. За способом лікування: I група - міні-інвазивні методи - 56 (54,9 \%) випадків; II група - лапаротомні втручання - $32(31,4 \%)$.

Результати дослідження. При застосуванні лапароскопічних методів середній ліжко-день склав $4,5 \pm 1,0$, післяопераційні ускладнення - 1 (1,8 \%) випадок. При лапаротомних способах відповідно: $12,0 \pm 1,5$ та 2 (6,3 \%), що підтверджує перевагу міні-інвазивних методів. Рецидив - у 3 (2,9 \%) випадках.

\section{Висновки:}

1. Для запобігання розвитку небезпечних ускладнень непаразитарних кіст печінки та з метою їх ранньої діагностики рекомендовано застосовувати променеві методи дослідження та ліквідовувати їх міні-інвазивними способами на ранній стадії формування.

3. Застосування міні-інвазивного методу фенестрації кіст з деепітелізацією їх оболонок при полікістозі печінки $є$ операцією вибору, що дає змогу уповільнити розвиток гепатоцелюлярної недостатності.

4. Поєднання міні-інвазивних методик з біполярною коагуляцією, чи лазерною дисекцією, чи зварювальною електрокоагуляцією призвело до зменшення таких ускладнень як інтраопераційна кровотеча і жовчопідтікання; стало можливим їх застосування не тільки при кістектомії великих ускладнених кіст, а й при резекційних методах лікування.

5. Застосування зварювального електрокоагулятора ЕК-300М “Свармед” при лапароскопічній цистектомії призвело до зменшення тривалості операції та перебування в стаціонарі в 2 рази, кількість рецидивів - 3 10 до $2,9 \%$.

Ключові слова: непаразитарні кісти печінки, полікістоз, міні-інвазивні методи.

Вступ. До недавнього часу непаразитарні кісти печінки (НКП) серед інших доброякісних утворень печінки вважалися рідкісним захворюванням, частота прижиттєвої діагностики не перевищувала $0,14-0,8 \%$ та $1,86 \%$ за результатами аутопсії [1]. Впровадження в клінічну практику сучасних неінвазивних променевих методів обстеження дало змогу підвищити діагностику НКП до $7 \%$ від загального числа населення $[2,3]$ та до 11,8 \% від загальної кількості доброякісних осередкових утворень печінки [4].

Кісти печінки класифікують в залежності від морфологічного виду епітеліальної оболонки [5]. Справжні кісти включають: вроджену просту кісту печінки та полікістозну хворобу, які мають генетично детермінований характер і виникають із аберантних жовчних протоків; паразитарну (гідатидну) кісту; неопластичну кісту та кісти, пов'язані з жовчовивідними протоками (хвороба Каролі, подвоєння жовчних протоків та перибіліарні кісти). Помилкові кісти можуть бути спричинені мимовільним внутрішньопечінковим крововиливом, посттравматичною гематомою або внутрішньопечінковою біломою [6].

За даними авторів, ультразвукове дослідження (УЗД) при діагностиці НКП має чутливість й ефек- тивність 85-95 \%, комп'ютерна томографія (КТ) $95 \%$, магнітно-резонанстна томографія (МРТ) - $98 \%$ [7].

Пріоритетним методом обстеження для більшості лікарів було УЗД, де НКП, як правило, зображена тонкою стінкою порожнини кісти круглої або овальної форми з рівними контурами без ехогенних елементів та відсутністю ехо-сигналів з внутрішнього простору. КТ і МРТ давали точніше уявлення про розміри, локалізацію і поширеність процесу та особливо важливими були при діагностиці НКП, ускладнених інфікуванням, кровотечею, малігнізацією, розвитком цистобіліарної нориці, механічної жовтяниці та портальної гіпертензії, здавленням шлунка або дванадцятипалої кишки 3 порушенням пасажу, розриву ії оболонки з розвитком перитоніту чи гемоперитонеуму [8].

При диференційній діагностиці НКП з ехінококовою кістою в сумнівних випадках, крім променевих методів діагностики, застосовують серологічні реакції на ехінокок: реакція латекс-аглютинації, непряма гемаглютинація, імуноферментний аналіз, діагностична чутливість яких сягала до 100 \% [9]. 
Методи лікування НКП характеризуються значним різноманіттям. Спочатку інтерес виник до черезшкірного пункційного лікування НКП під контролем УЗД. Поєднання пункційного і пункційнодренажного лікування із склерозуючою і місцевою антибактеріальною терапією давало кращі результати і її вважали оптимальною. Позитивний досвід, накопичений у деяких клініках, навіть дозволив рахувати таке лікування методом вибору й використовувати при ускладнених і багатокамерних кістах, а також при підозрі на пухлинний генез [10]. 3 метою деепітелізації для обробки порожнини кісти використовували $96 \%$ розчин спирту, 0,02\% розчин декаметоксину (декасан), $10 \%$ розчин повідон-йоду, $1 \%$ розчин гідроксиметилхіноксиліндіоксиду (діоксидин), $0,1 \%$ розчин октенідину та інші склерозанти, а також різні методи електрокоагуляції, у тому числі безконтактну коагуляцію у спрей-режимі, аргоноплазменну коагуляцію, гідротермокоагуляцію (безконтактна коагуляція у водному середовищі) тощо [11].

У 1968 p. T. Lin вперше описав операцію фенестрації кіст печінки, яка в даний час набула чи найбільшого поширення і визнання. У сучасній модифікації фенестрація печінки набула широкого поширення, у тому числі і в лапароскопічній хірургії, i визнана операцією вибору при неускладнених кістах. У той же час оцінка віддалених результатів свідчить, що проста пункція кіст з аспірацією вмісту без деструкції покривного епітелію призводить до швидкого рецидиву захворювання майже в $100 \%$. Аналіз даних літератури показав, що пункційне і пункційнодренажне лікування кіст печінки набуло широкого поширення практично лише в середовищі російських хірургів [12]. Для поліпшення дренування неглибоко розташованих інтрапаренхіматозних кіст рекомендують поєднувати фенестрацію $з$ частковою резекцією печінки. Деякі автори для посилення резорбтивних процесів застосовують тампонаду частини кісти, що залишилася, сальником на судинній ніжці. Мабуть, безпека і привабливість методики зумовили розширення показів до втручання та активного лікування безсимптомних кіст невеликого розміру, які не потребують операції. Це послужило приводом для їх поступового впровадження в клінічну практику, що виразно прослідковується по наростаючому числу повідомлень у літературі $[13,14]$.

При полікістозі 3 великих кіст, обмежених ділянкою печінки, радять виконувати пункційноаспіраційну склеротерапію та фенестрацію. Інші автори вважають за доцільне виконувати сегментарну резекцію або навіть трансплантацію печінки [6].

Використання скошеного $30^{\circ}$ лапароскопа дозволило розширити можливості візуалізації, особливо при розташуванні кісти в задніх сегментах печінки [15]. Операція полягала у висіченні виступаючої частини кісти $з$ утворенням сполучення іï з черевною порожниною [10]. Для висічення виступаючої частини кісти використовувалися стандартні лапароскопічні інструменти, гемостаз забезпечувався використанням стандартної монополярної коагуляції [16]. Остерігаючись можливої кровотечі із стінки кісти, автори обмежували зону резекції ділянкою капсули 3 відступом від паренхіми на 3-5 мм. Подальші пові- домлення відображали пошук хірургами, направлений на удосконалення методики операції з метою підвищення iï радикальності і безпеки. Для ефективного гемостазу по краях резекції використовують кліпування, аргоноплазменну коагуляцію, а також ультразвукові ножиці, що забезпечують пересічення тканини $з$ одночасним гемостазом. При цьому рівень конверсії досягає $10 \%$ й обумовлений в основному безуспішними спробами зупинки кровотечі з країв стінки кісти після резекції. Аналіз інших авторів показує, що лапароскопічна операція - це ефективне втручання 3 малою частотою інтраопераційних ускладнень.

Взагалі, післяопераційні ускладнення спостерігаються в 2-5 \% хворих, найчастіше зустрічаються абсцеси в ділянці кісти. У віддаленому періоді частота рецидивів відмічається в широкому діапазоні - від 0 до $20 \%$, що, на думку багатьох авторів, пояснюється відмінностями в методиці виконання втручання [6].

Обгрунтування дослідження. Хоча зростання захворюваності населення на НКП носить відносний характер, обумовлений поліпшенням якості діагностики, загальне збільшення числа хворих, що звертаються за медичною допомогою, ставить це захворювання в ряд актуальних проблем сучасної хірургії. НКП також пов'язані з генетичними порушеннями, такими як полікістоз печінки або хвороба Каролі. Як правило, у пацієнтів з НКП менше 3 см хвороба протікає безсимптомно. Ці кісти стають симптоматичними, коли великі, множинні або ускладнені. УЗД найкраща та найдешевша модель візуалізації діагностики НКП, але вона повинна бути завершена іншими візуальними та серологічними тестами. Важливо диференціювати просту кісту печінки від гідатидної кісти, цистаденоми та цистаденокарциноми, перш ніж приступати до лікування. Проте не існує певного надійного критерію для диференціації цистаденоми від цистаденокарциноми, і правильний діагноз часто ставиться лише при гістопатології. Також є рідкісні печінкові кістозні ураження, які необхідно враховувати [8].

Вибір лікувальної тактики залишається індивідуальним і залежним від розмірів кісти, локалізації, тривалості захворювання, їх ускладнень, супутньої патології. Таким чином, більшість авторів вважають, що безсимптомні поодинокі кісти печінки потребують лише спостереження, тоді як симптоматичні та ускладнені потребують хірургічного втручання. Незважаючи на значні успіхи в хірургічній гепатології, досягнуті за останні роки, проблему клінічного виявлення і впровадження чітких лікувально-тактичних критеріїв НКП до цих пір кінцево не вирішено.

Інша група авторів висловлює думку, що більшість хворих з НКП не потребують оперативного лікування, клінічний перебіг у них безсимптомний.

Багато зарубіжних авторів вважають, що голкова аспірація та інші подібні маніпуляції, у тому числі введення в порожнину кісти склерозуючих речовин, небезпечні, неадекватні в лікувальному аспекті і у ряді спостережень призводять до тяжких наслідків. Введення в порожнину кісти склерозуючих речовин може приховувати в собі певну небезпеку у 
вигляді пошкодження незміненої прилеглої паренхіми печінки і кровотечі в порожнину кісти. Черезшкірна аспірація кісти під контролем УЗД - це мініінвазивна процедура, як правило, пов'язана зі склеротерапією. Проте серії ранніх клінічних спостережень інших хірургів показали, що дана методика небезпечна і не завжди дозволяє добитися декомпресії кіст.

Деепіляція інтрапаренхіматозної частини кісти розглядається авторами як один 3 найважливіших етапів операції, який визначає іiі радикальність і забезпечує добрі результати. Найвищі показники успіху були зареєстровані при лапароскопічній або відкритій кістекомії.

Як правило, про необхідність хірургічного втручання ставлять питання при симптомних і ускладнених НКП незалежно від їх розміру. При цьому немає єдиної думки щодо розмірів кіст, при яких слід використовувати активну хірургічну тактику. Вважають, що операція показана при гігантських кістах. Деякі автори дотримуються активнішої хірургічної тактики, рахуючи показами до операції кісти діаметром 5 см і більше. Автори вважають виправданим хірургічне втручання при поєднанні кіст печінки 3 іншим захворюванням, що потребує хірургічного лікування.

Тенденція впровадження в лікувальну практику малоінвазивних технологій, спостережувана останнім часом, багато в чому перетворила підхід до хірургічного лікування НКП, визначивши пріоритет сучасних методик.

Поняття "рецидив" прийнятне лише до радикальних операцій (резекція печінки або періцистектомія). Повторне утворення кіст після фенестрації обумовлено заповненням резидуальної кістозної порожнини, при цьому більш коректне поняття "вторинне наповнення кіст". Серед основних чинників захворювання виділяють недостатнє висічення виступаючої частини кісти, великі розміри кіст, неповноцінну деепітелізацію, а також полікістозну хворобу. Як несприятливий чинник рецидиву виділяють також локалізацію кіст в задніх сегментах печінки. Остерігаючись можливої кровотечі із стінки кісти, автори обмежували зону резекції ділянкою капсули 3 відступом від паренхіми на 3-5 мм. Подібна тактика неминуче привела до погіршення віддалених результатів, які супроводжувалися великою частотою утворення залишкової порожнини, особливо в тих серіях спостережень, в яких не проводилася деепітелізація кісти.

Особлива тактика при полікістозі печінки. У 1997 p. Gigot J.F. та його співробітники описали класифікацію на основі кількості та розмірів печінкових кіст та залишкової нормальної паренхіми печінки між цистами. Цей опис заснований на передопераційній КТ. Також ця класифікація може окреслити лікувальну стратегію:

тип I - менше 10 великих кіст (7 - 10 см) 3 великими ділянками нецистної паренхіми (можлива ультразвукова черезшкірна аспірація чи фенестрація зі склерозуванням оболонки кісти);

тип II - дифузне ураження паренхіми печінки кістами середнього розміру $(5-7 \mathrm{~cm})$ із залишками великих ділянок нецистної паренхіми (можлива фе- нестрація з деепіляцією інтрапаренхіматозної частини кіст);

III тип - масивне, дифузне залучення печінкової паренхіми кістами малого та середнього розміру (менше 5 см) та лише декілька областей нормальної паренхіми печінки між цистами (резекційні способи лікування або трансплантація печінки) [17].

Вважають, що міні-інвазивні методи є здійсненними та безпечними, альтернативою відкритим підходам до лікування НКП. Найбільш використовувані методи - черезшкірний дренаж, лапароскопічна фенестрація та лапароскопічна гепатектомія. Однак будь-який метод, що є кращим у кожному випадку, залежить від типу кістозного ураження, його розмірів та локалізації в печінці. Для цього потрібно більше досліджень, щоб краще визначити точні показання до застосування одного із міні-інвазивних способів.

Дотримання сучасних принципів лапароскопічного лікування НКП дозволяє досягнути добрих віддалених результатів з рівнем рецидиву до $10 \%$, у порівнянні $з$ результатами фенестрації печінки при лапаротомії. Не дивлячись на добрі результати, відмічені при лапароскопічному лікуванні кіст цієї локалізації, деякі автори підкреслюють складність подібних втручань, що вимагають специфічних прийомів i часткової мобілізації печінки. При цьому раннє формування зрощень між стінкою кісти і діафрагмою приводить до більшого ризику утворення залишкової порожнини, яка при неадекватному дренуванні та неповноцінній деепітелізації може досягати значних розмірів. Проте технічна доцільність та хороші коротко- та середньострокові результати зробили лапароскопічний підхід у більшості випадків процедурою вибору для лікування симптоматичних кіст печінки [18].

Таким чином, при проведенні даного аналізу встановлено ряд невирішених проблем у діагностиці та в підходах хірургічного лікування НКП та їх ускладнень.

Мета дослідження: покращити результати хірургічного лікування непаразитарних кіст печінки за рахунок розробки та удосконалення методів оперативного втручання.

Матеріали та методи. У клініці хірургії № 1 Вінницького національного медичного університету ім. М.I. Пирогова, яка знаходиться на базі хірургічного відділення Вінницької обласної клінічної лікарні ім. М.І. Пирогова, з 2004 по 2019 рр. було прооперовано 102 хворих з кістозними ураженнями печінки, де у $88(86,3 \%)$ випадках були НКП; у $14(13,7 \%)-$ полікістоз, із них у $10(71,4 \%)-3$ ураженням печінки за Гіготом типів I-II, та у 4 (28,6 \%) пацієнтів мали місце важкі форми полікістозу з симптомами портальної гіпертензії та здавленням внутрішньопечінкових жовчних протоків (тип III за Гіготом). Жінок було 72 (70,6 \%), чоловіків - 30 (29,4\%). Середній вік становив $52,5+2,0$ років. УЗД та КТ проводили у всіх випадках для оцінки характеристик, розмірів та точного положення ураження. МРТ було виконано 4-м $(3,9 \%)$ хворим з полікістозом II типу та 2-м (2,0 \%) хворим 3 цистобіліарною норицею. Локалізація кісти в одному сегменті печінки визначена у 62 (70,5\%) хворих, $з$ яких у $\mathrm{S}_{\mathrm{I}}$ - розташовувалася у 2 (2,3 \%) па- 
цієнтів, $\mathrm{S}_{\text {II }}$ - у $8(9,1 \%), \mathrm{S}_{\mathrm{IV}}$ - у $6(6,8 \%), \mathrm{S}_{\mathrm{V}}-$ у 23 $(26,1 \%), S_{V I}-$ y $14(15,9 \%), S_{V I I}-$ y $4(4,5 \%), S_{V I I I}$ - y 5 $(5,7 \%)$. Кіста захоплювала кілька сегментів печінки у $26(29,5 \%)$ хворих, а саме $\mathrm{S}_{\text {I-IV }}$ - у $1(3,8 \%), \mathrm{S}_{\mathrm{II}-\mathrm{III}}$ - у 4 $(15,4 \%), \mathrm{S}_{\text {IV-V }}$ - y $6(23,1 \%), \mathrm{S}_{\mathrm{V}-\mathrm{VI}}$ - y $2(8,0 \%), \mathrm{S}_{\mathrm{V}-\mathrm{VIII}}-$ y $10(38,5 \%), S_{\text {VII-VIII }}-$ y $1(3,8 \%), S_{\text {IIIIV }}$ - y $1(3,8 \%)$, $\mathrm{S}_{\text {III,IV-V }}$ - y 1 (3,8 \%). Таким чином, у $86(97,7 \%)$ НЗП були солітарні, із них у 12 (14,0\%) пацієнтів локалізувалися в лівій долі печінки, у 74 (86,0 \%) - в правій частці; білобарно - у 2 (2,3\%). Діаметр кіст коливався від 2,2 до 25 см. Кісти печінки до 5 см в діаметрі виявлені у 38 (43,2\%) хворих, 5 -10 см - у $25(28,4$ \%), 10-20 см - у $23(26,1 \%)$ і більше $20-25 \mathrm{~cm}-$ у 2 $(2,3 \%)$.

У $72(81,8 \%)$ спостереженнях клінічний перебіг НКП був безсимптомним, патологію виявляли випадково при обстеженні з приводу іншого захворювання. Клінічні прояви спостерігали лише в 26 (29,5 \%) хворих при прогресуванні хвороби. Пацієнти відзначали відчуття важкості або болю в правому підребер'ї та в епігастральній ділянці, нудоту, гіркоту та сухість у ротовій порожнині, дискомфорт у животі, здуття після їжі. Ускладнені НКП спостерігали у 10 $(11,4 \%)$ хворих. У 2-х (2,3 \%) хворих були діагностовані великі кісти центрального розташування розмірами 25 х $18 \mathrm{~cm}^{2}$ та 22 х $16 \mathrm{~cm}^{2}$ призводили до здавлення елементів гепатодуоденальної зв'язки печінки 3 розвитком симптомів механічної жовтяниці і портальної гіпертензії. В 1 (1,1 \%) випадку НКП ускладнилася крововиливом в порожнину кісти, в 4-х $(4,5$ \%) - 3 клінікою абсцедування, у 2 (2,3 \%) - нагноєння кісти зі спонтанним розривом та формуванням дифузного гнійно-фібринозного перитоніту, в 1 (1,1\%) розрив кісти 3 кровотечею в черевну порожнину 3 гемоперитонеумом. Ознаки гепатоцелюлярної недостатності II -III ст. активності спостерігали у 4 (3,9 \%) пацієнтів з важкими форми полікістозу та у 2 (2,0 \%) хворих із НКП з механічною жовтяницею.

\section{За способом лікування:}

I група - міні-інвазивні методи, які були впроваджені з 2007 року, що склали 56 (54,9 \%) випадків, а саме: пункція та аспірація вмісту кісти під УЗД - контролем - 8 (14,3 \%); пункція, зовнішнє дренування під УЗД-контролем 3 періодичним введенням склерозуючого розчину - 5 (8,9 \%); висічення передньої стінки кісти, деепітелізація залишкової порожнини, введення в залишкову порожнину склерозуючого фактора, зовнішнє дренування з міні-доступу - 8 (14,3\%); 3 міні-доступу за допомогою апарату "Мініасистент" в ділянках печінки $\mathrm{S}_{\mathrm{III}}$ - VI (доступ залежав від розташування вогнищевого осередку, розміром не більше 4-х см) висічення передньої стінки кісти, деепітелізація залишкової порожнини, оментоцистопексія, зовнішнє дренування - 8 (14,3\%), а також хворим 3 ризиком проведення карбопневмоперитонеума; лапароскопічна фенестрація з деепіляцією інтрапаренхіматозної частини кісти - 10 (17,9 \%); лапароскопічне висічення передньої стінки кісти, деепітелізація залишкової порожнини, зовнішнє дренування - 6 $(10,7 \%)$; лапароскопічна сегментарна резекція печінки - 9 (16,1\%); лапароскопічна перицистектомія - 2 (3,6 \%). Середній ліжко-день склав 4,5 $\pm 1,0$, середня тривалість операції - $1,2 \pm 0,5$ години.
II-й групі хворих, що склали 32 (31,4 \%) пацієнти, були виконані лапаротомні втручання: висічення кісти, оментогепатопексія, дренування - 4 (12,5 \%); пункція, дренування кісти - 2 (6,3\%); висічення кісти, дренування - 4 (12,5\%); дренування кісти та абсцесу печінки - 2 (6,3\%); енуклеація гемангіоми (діагностично було сприйнято за посттравматичну кісту, що було підтверджено УЗД, заключний діагноз був встановлено гістологічно) - 2 (6,3\%); сегментарна резекція печінки - 9 (28,1\%); атипова резекція печінки - 3 (9,4 \%); лівобічна гемігепатектомія - 1 (3,1\%); перицистектомія - 6 (18,8\%). Дані оперативні втручання виконували 3 верхньосерединного доступу в 10 (31,3 \%) хворих, косі підреберні доступи за Кохером або Федоровим - у 22 (68,8 \%). Середній ліжко-день склав $12,0 \pm 1,5$, середня тривалість операції - 2,2 $\pm 0,5$ години.

У випадках поєднаної патології органів черевної порожнини симультанні операції в I-й групі 3 міні-інвазивними методиками були виконані 24 (42,9 \%) пацієнтам, а саме: лапароскопічна холецистектомія - 12 (50,0\%) (хронічний та гострий калькульозний холецистит); лапароскопічні гінекологічні операції 8 (33,3\%); трансабдомінальна преперитонеальна енодогерніопластика - 4 (12,5\%); у II групі з лапаротомними доступами - 3 (9,4 \%), а саме: алогерніопластика великої вентральної грижі - 1 (33,3 \%); правобічна геміколектомія при інтраоперційній діагностиці C-r colli - 1 (33,3 \%), пілородуоденопластика за Джадом при ліквідації рубцево-виразкового дефекту 3 ознаками субкомпенсованого стенозу розміром - 1 (33,3 \%). В останніх 2 операціях було вирішено провести цистектомію через напруженість капсули кісти печінки та ризик іiі розриву (включаючи ятрогенний момент через локалізацію $\mathrm{S}_{\mathrm{IV}-\mathrm{V}}$ ).

У першій групі хворих кількість післяопераційних ускладнень мала місце в 1 (1,8\%) у вигляді жовчопідтікання, у другій групі - в 2 (6,3\%) у вигляді піддіафрагмального абсцесу та кровотечі із залишкової порожнини великої НКП. Післяопераційна летальність мала місце в 1 (7,1\%) випадку в групі хворих 3 полікістозом та 3 вираженою гепатоцелюлярною недостатністю. Решта пацієнтів одужали.

При досліджені віддалених результатів протягом 3-10 років рецидив мав місце у 3-х (2,9\%) випадках, хворі $з$ полікістозом не враховувались.

Статистичну обробку результатів дослідження виконували за допомогою пакету прикладних програм «Statistica 5.5» фірми Statsoft (належить ЦНІТ BНМУ ім. М. І. Пирогова, ліцензійний номер № AXXR910A374605FA).

Результати дослідження. Для визначення способу та об'єму оперативного лікування скарги хворого не мали значення, так як у більшості випадків розвиток ускладнень, крім гнійно-запальних, мав малосимптомний перебіг. Тому більшу увагу надавали діагностичній цінності променевих методів досліджень. Так проблему підтвердження доброякісного генезу кістозного утворення в більшості випадків вдалось усунути завдяки доступному УЗД. КТ застосовували згідно з протоколом для уточнення локалізації процесу та його ускладнень. МРТ було проведе- 
но 6 (6,8 \%) хворим для діагностичного уточнення цистобіліарних нориць.

В 2-х (2,3\%) випадках, де були сумніви щодо непаразитарного характеру кіст, провели імуноферментний аналіз та в 4-х (4,5 \%) хворих при підозрі на малігнізацію проведено визначення відсутності злоякісного генезу онкомаркерами та морфологічним дослідженням вмісту діагностичної пункції кісти. Проте навіть після проведення всього комплексу передопераційного обстеження в одному випадку остаточну діагностику провели інтраопераційно за допомогою візуальної ревізії і виконання термінового гістологічного дослідження.

У $8(11,4 \%)$ хворих мали місце ускладнені НКП, а саме: в $1(1,1 \%)$ випадку - крововилив в порожнину кісти; в 4-х (4,5\%) - абсцедування кісти; у 2 $(2,3 \%)$ - нагноєння кісти зі спонтанним розривом та 3 дифузним гнійно-фібринозним перитонітом; в 1 (1,1 \%) - розрив кісти 3 кровотечею з гемоперитонеумом - потребували екстрених оперативних втручань i були прооперовані в перші 6 годин. У 4 (3,9\%) пацієнтів 3 важкими форми полікістозу та у 2-х (2,3\%) хворих були діагностовані великі кісти центрального розташування розмірами $25 \times 18 \mathrm{~cm}^{2}$ та $22 \mathrm{x} 16 \mathrm{~cm}^{2}$, які призводили до здавлення елементів гепатодуоденальної зв'язки печінки з розвитком симптомів механічної жовтяниці і портальної гіпертензії, були прооперовані в першу добу в ургентно-відстроченому порядку. Всі інші пацієнти були прооперовані в плановому порядку. Слід відзначити, що пункцйноаспіраційну методику 3 введенням склерозуючих розчинів, яка була проведена $23(26,1 \%)$ хворим 3 НКП та метод фенестрації - 8 (57,1\%) хворим 3 полікістозом, можна, швидше всього, віднести до паліативних методів. Саме у цій групі у 3 -х (3,4 \%) хворих 3 НКП мав місце рецидив захворювання. У всіх інших, як при міні-іназивних, так і при лапаротомних способах оперативного лікування рецидивів захворювання не спостерігали.

Звертає увагу те, що при застосуванні лапароскопічних методів оперування середній ліжко-день склав $4,5 \pm 1,0$, післяопераційне ускладнення мало місце в 1 (1,8 \%) випадку, у порівнянні з лапаротомними способами, при яких середній ліжко-день склав $12,0 \pm 1,5$ та було 2 (6,3 \%) випадки післяопераційного ускладнення, що підтверджує переваги мініінвазивної тактики лікування. Не дивлячись на привабливість лапароскопічних цистектомій, виконувати iii в $\mathrm{S}_{\mathrm{I}}$, viI та у $\mathrm{S}_{\mathrm{VII}}$ на даний час ризиковано.

Обговорення результатів. Безсимптомність перебігу хвороби безумовно ускладнює тактику лікування [1]. Завдяки доступності УЗД 78 (88,6\%) хворих з НКП та $13(92,9$ \%) з полікістозом знали свій діагноз до останнього звернення в медзаклад, із них $10(11,4$ \%) хворих з НКП та 4 (3,9\%) з полікістозом змушені оперуватися через розвиток небезпечних для життя ускладнень [7]. 27 (30,7 \%) хворих дали згоду на операцію тільки за наявності супутньої хірургічної патології. Завдяки розвитку міні-інвазивних методів хірургічного лікування НКП вдалось застосувати дані способи у 56 (63,6 \%) пацієнтів, що є своєрідним “проривом". У даній ситуації частково “винні” самі хірурги, які притримуються стриманої тактики при неускладнених та при невеликих розмірах НКП [18].

При полікістозі зовсім інша ситуація. Як правило, у більшості випадків хворі з даною патологією адекватно оцінюють свій стан і 3 легкістю дають згоду на операцію. Проте радикальний підхід при даній патології - це трансплантація печінки. Однак не всім хворим з різних причин дане оперативне втручання доступне, незалежних від роботи медичних працівників. Для більшості українців єдиний вихід у даній ситуації - це своєчасна фенестрація з деепітелізацією оболонок кіст чи резекційні методи в залежності від типу пошкодження паренхіми печінки за Gigot J.F. (1997). Паліативність даних методів обумовлена рецидивом захворювання внаслідок так званого "вторинного наповнення кіст". Крім цього як в інтраопераційний, так і в післяопераційний періоди маємо ризик розвитку кровотечі та жовчопідтікання [17].

Міні-інвазивні методики через свої переваги (малотравматичність, швидша реабілітація, косметичність) поступово витісняють лапаротомні методи лікування даної патології. Пункційний метод лікування під контролем УЗД доцільно проводити при кістах або абсцесах (діаметром до 4-8 см) печінки, розташованих у глибині паренхіми печінки, особливо в осіб похилого віку з коморбідною патологією та виснажених. Показання до лапароскопічних операцій 3 кожним роком розширяються. Так, ще 5 років тому вважали можливим застосування даного методу у вигляді фенестрації при наявності неускладнених кіст діаметром до 10 см. Поєднання міні-інвазивних методик з біполярною коагуляцією, чи лазерною дисекцією, чи зварювальною електрокоагуляцією призвело до зменшення таких ускладнень як інтраопераційна кровотеча і жовчопідтікання, та зробило можливим їх застосування не тільки при кістектомії великих ускладнених кіст, а й при резекційних методах лікування. Лапаротомні методи лікування слід застосовувати при потребі “конверсії" в результаті неможливості усунення ускладнень, що розвинулось ятрогенно під час міні-інвазивної операції та при лапароскопічній діагностиці (крупні цистобіліарні нориці), а також при локалізації патологічного процесу в сегментах

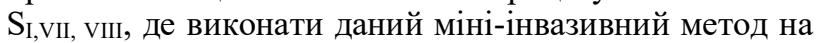
сьогодні неможливо. Таким чином, не дивлячись на успіхи в лікуванні даної патології, є “поле” для подальшої розробки та удосконалення способів лікування даної патології.

\section{Висновки:}

1. Для запобігання розвитку небезпечних ускладнень непаразитарних кіст печінки та 3 метою їх ранньої діагностики рекомендовано застосовувати променеві методи дослідження та ліквідовувати їх міні-інвазивними способами на ранній стадії формування.

2. Пункційно-аспіраційні способи лікування непаразитарних кіст із зовнішнім дренуванням 3 періодичним введенням склерозуючих розчинів під ультразвуковим контролем мають паліативний характер, про що свідчить наявність рецидивів (3,4\%). Їх застосування рекомендовано хворим похилого віку з високою коморбідністю супутньої патології чи як підготовчий етап до радикальної операції. 
3. Застосування міні-інвазивного методу фенестрації кіст з деепітелізацією їх оболонок при полікістозі печінки є операцією вибору, що дає змогу уповільнити розвиток гепатоцелюлярної недостатності.

4. Поєднання міні-інвазивних методик з біполярною коагуляцією, чи лазерною дисекцією, чи зварювальною електрокоагуляцією призвело до зменшення таких ускладнень як інтраопераційна кровотеча і жовчопідтікання, та зробило можливим їх застосування не тільки при кістектомії великих ускладнених кіст, а й при резекційних методах лікування.

5. Застосування зварювального електрокоагулятора ЕК-300М “Свармед” при лапароскопічній цистектомії призвело до зменшення тривалості операції та перебування в стаціонарі в 2 рази, кількість рецидивів - 310 до 2,9\%. Через анатомічні особливості застосовувати даний метод лікування можливо при локалізації непаразитарної кісти в II - vI сегментах печінки.

\section{References:}

1. Stoyka VI. Arhonoplazmova koahulyatsiya -rozvytok ta vprovadzhennya $\mathrm{v}$ khirurhichnu praktyku. Visnyk Vinnytskoho natsional'noho medychnoho universytetu. 2013; 17(2):527-531. file:///D:/users/user/ Downloads/ vvnmu $2013 \quad 172$ 57.pdf

2. Vakulenko IP, Khatsko $\overline{\mathrm{V}} \overline{\mathrm{V}}$, Shatalov AD, Kuzmenko AE, Fomynov VM, Voytyuk VN. Vozmozhnosti kompyuternoy I magnitno-rezonansnoy tomografii $\mathrm{v}$ diagnostike zhidkostnykh ochagovykh obrazovaniy pecheni. Aktualnyye voprosy terapii: elektronnyy sbornik materialov yezhegodnoy nauch.-prakt. konf. 2016; 25:18-22. Available from: https://dnmu.ru/wpcontent/uploads $/ 2016 / 04 / \%$ D1\%8D \%D0\%BB\%

3. Tretyakov AA, Neverov AN, Petrov SV, Shchetinin AF, Glebov VYU. Khirurgicheskaya taktika pri ochagovykh obrazovaniyakh v pecheni (po materialam oblastnogo gepatologicheskogo tsentra). Orenburgskiy meditsinskiy vestnik. 2016; 4(16):28-32. Available from:

https://cyberleninka.ru/article/n/hirurgicheskayataktika-pri-ochagovyh-obrazovaniyah-v-pecheni-pomaterialam-oblastnogo-gepatologicheskogotsentra/viewer

4. Kolkin YAH, KhatskoVV, Shatalov OD, Parkhomenko GV, Potapov VV. Operatyvne likuvannya khvorykh na dobroyakisni oseredkovi utvorennya pechinky. Aktualni problemy suchasnoyi medytsyny: Visnyk ukrayinskoyi medychnoyi stomatolohichnoyi akademiyi. 2013; 1(41):122-124. Available from: https://cyberleninka.ru/article/n/operativne-

likuvannya-hvorih-na-dobroyakisni-oseredkoviutvorennya-pechinki/viewer

5. Abou-Shady M, Zakaria H, Alwaraky M. Nonparasitic liver cysts: different treatment strategies. The Egyptian Journal of Surgery. 2016; Nov; 35(4):438444. DOI: $10.4103 / 1110-1121.194724$

6. Shaprynskyy VO, Makarov VM, Lutsker OL, Pobirchyy MR. Rol ultrazvukovoyi diahnostyky ta spiralnoyi kompyuternoyi tomohrafiyi v diahnostytsi ta likuvanni abstsesiv pechinky. Visnyk Vinnytskoho natsionalnoho medychnoho universytetu. 2017;
21(2):485-488. [InUkrainian]. file:/// C:/Users/User/ Downloads/vvnmu_2017_21_2_30.pdf

7. Sturm AK, Welsch T, Meissner C, Aust DE, Baretton G. A case of biliary adenofibroma of the liver with malignant transformation: a morphomolecular case report and review of the literature. Surg Case Rep. 2019; Jun 24; 5(1):104. doi: 10.1186/s40792-0190661-2.

8. Vetshev PS, Musayev GKH, Fatyanova AS. Ekhinokokkoz: osnovy diagnostiki i rol miniinvazivnykh tekhnologiy (obzor literatury). Annaly khirurgicheskoy gepatologii. 2018; 20(3):47-53. DOI: 10.16931/1995-5464.2015347-5.

9. Freynd GG, Zhivayeva YEV. Morfogeneticheskiye varianty neparazitarnykh kist pecheni. Eksperimentalnaya i klinicheskaya gastroenterologiya. 2018; 8(156):94-98. DOI: 10.31146/1682-8658-ecg-156-894-98.

10. Sigua BV, Zemlyanoy VP, Kachiuri AS, Gurzhiy DV, Abdulayeva RM, Vinnichuk SA, Zakharov YEA. Endovideokhirurgiya $\mathrm{V}$ lechenii bolshikh neparazitarnykh kist pecheni. Vestnik SeveroZapadnogo gosudarstvennogo meditsinskogo universiteta im. II Mechnikova. 2019; 11(1):55-60. Available https://doi.org/10.17816/mechnikov201911155-60

11. Shaprynskyy VO, Makarov VM, Nazarchuk OA, Suleymanova VH. Vybir antyseptykiv dlya mistsevoyi sanatsiyi abstsesiv pechinky. Art of medi$\begin{array}{lll}\text { cine. } & \text { 2018; } & \text { (3):153-157. file:/// }\end{array}$ C:/Users/User/Downloads/ artmed_2018_3_31\% 20(2).pdf

12. Murunova YUN, Darvin VV. Rol maloinvazivnykh tekhnologiy v khirurgicheskom lechenii neparazitarnykh kist pecheni. Kubanskiy nauchnyy meditsinskiy vestnik. 2017; 3:66-70. DOI: 10.25207 / 1608-6228-2017-24-3-66-70

13. Kisiel A, Vass DG, Navarro A, John AK, Isaac J, Marudanayagam R, Mirza DF, Muiesan P, Roberts K, Sutcliffe RP. Long-term patient-reported outcomes after laparoscopic fenestration of symptomatic liver cysts. Surg Laparosc Endosc Percutan Tech. 2017; Aug; 27(4):e80-e82. doi: 10.1097/SLE .000000000 0000441

14. Leombroni M, Buca D, Celentano C, Liberati M, Bascietto F, Gustapane S, Marrone L, Manzoli L, Rizzo G, D'Antonio F. Outcomes associated with fetal hepatobiliary cysts: systematic review and meta-analysis. Ultrasound Obstet Gynecol. 2017; Aug; 50(2):167-174. doi: 10.1002/uog.17244

15. KolkinYAG, Khatsko VV, Shatalov AD, Dudin AM, Fominov VM, Parkhomenko AV. Otdalonnyu rezultaty khirurgicheskogo lecheniya bolnykh s neparazitarnymi kistami pecheni s pozitsii otsenki kachestva zhizni. Vestnik gigiyeny i epidemiologii. 2018; 22(4):37-40. file://C:/Users/User/Downloads/ 193D0\%A2\%D0\%B5\%D0\%BA \%D1\%81\%D1\%82\% $20 \% \mathrm{D} 1 \% 81 \% \mathrm{D} 1 \% 82 \% \mathrm{D} 0 \% \mathrm{~B} 0 \% \mathrm{D} 1 \% 82 \% \mathrm{D} 1 \% 8 \mathrm{C} \%$ D0\%B8-406-1-10-20190129\%20(1).pdf

16. Van Rosmalen BV, Bieze M, Besselink MG, Tanis P, Verheij J, Phoa SS, Busch O, van Gulik TM. Longterm outcomes of resection in patients with symptomatic benign liver tumours. HPB (Oxford). 2016; 
Nov; 18(11):908-914. doi: 10.1016/j.hpb. 2016.07.013.

17. Boeți MPS, Boroș M, Herlea V, Petrișor A, Popescu I. Diagnostic and Therapeutic Challenges in Nonparasitic Liver Cysts. Recent Advances in Liver Diseases and Surgery. 2015; Oct; 249. DOI: 10.5772/61057

18. Tartaglia N, DiLascia A, Cianci P, Vovola F, Pacilli M, Zita A, Fersini A, Ambrosi A. Surgical managemen to fnon-parasitichepatic cysts. A single center experience and a review of the literature. Ann Ital Chir. 2019; 90:514-519. https://pdfs.semantic schol$\begin{array}{llllll}\text { ar.org } \quad / 4 \mathrm{~b} 4 \mathrm{~d} / 8 & \text { e8 } & 50 \quad \text { e08080 } & 77747 \mathrm{~d}\end{array}$ 462ed89629ad40faa84.pdf

\section{УдК 616.36-003.4-089 \\ ХИРУРГИЧЕСКОЕ ЛЕЧЕНИЕ НЕПАРАЗИТАРНЫХ КИСТ ПЕЧЕНИ}

В.О. Шапринський, О.О. Воровский,

О.А. Каминский, Я.М. Пашинский, Ю.А. Миронишен

Винницкий национальный медицинский университет им. Н. И. Пирогова, кафедра хирургии №1

с курсом урологии,

2. Винница, Украина,

ORCID ID: 0000-0002-3890-6217,

ORCID ID: 0000-0002-8933-3965,

ORCID ID: 0000-0002-7753-6933,

ORCID ID: 0000-0002-3001-9955,

ORCID ID: 0000-0001-8837-2025,

e-mail: surgery1@vnmu.edu.ua

Резюме. Цель исследования: улучшить результаты хирургического лечения непаразитарных кист печени за счет разработки и совершенствования методов оперативного вмешательства.

Материал и методы. Прооперированы 102 больных: 88 (86,3 \%) -непаразитарные кисты печени, $14(13,7$ \%) - поликистоз. По способу лечения: I группа - мини-инвазивные методы - 56 (54,9 \%) случаев; II группа - лапаротомные вмешательства - 32 $(31,4 \%)$.

Результаты исследования. При применении лапароскопических методов средний койко-день составил 4,5 $\pm 1,0$, послеоперационные осложнения 1 $(1,8 \%)$ случай. При лапаротомных способах соответственно: $12,0 \pm 1,5$ и $2(6,3 \%)$, что подтверждает преимущество мини-инвазивноиех методов. Рецидив - в 3-х (2,9 \%) случаях.

\section{Выводы:}

1. Для предотвращения развития опасных осложнений непаразитарных кист печени и с целью их ранней диагностики рекомендуется применять лучевые методы исследования и ликвидировать их мини-инвазивными способами на ранней стадии формирования.

3. Применение мини-инвазивного метода фенестрация кист с деэпителизации их оболочек при поликистозе печени является операцией выбора, позволяет замедлить развитие гепатоцеллюлярной недостаточности.
4. Сочетание мини-инвазивных методик с биполярной коагуляцией, или лазерной диссекцией, или сварочной электрокоагуляцией привело к уменьшению таких осложнений как интраоперационная кровотечение и жовчопидтикання, и стало возможным их применение не только при кистэктомии больших осложненных кист, но и при резекционных методах лечения.

5. Применение сварочного электрокоагулятора ЭК-300М "Свармед" при лапароскопической цистэктомии привело к уменьшению продолжительности операции и пребывания в стационаре в 2 раза, количество рецидивов - с 10 до $2,9 \%$.

Ключевые слова: непаразитарные кисты печени, поликистоз, мини-инвазивные методы.

\section{UDC 616.36-003.4-089 \\ SURGICAL TREATMENT OF NON-PARASITAL LIVER CYSTS}

V.O. Shaprynskyi, O.O. Vorovskiy, O.A. Kaminsky, Ya.A. Pashinsky, Yu.A. Mironishen

National Pirogov Memorial Medical University, Vinnytsya, Department of Surgery No. 1 with a course in urology,

Vinnytsya, Ukraine

ORCID ID: 0000-0002-3890-6217,

ORCID ID: 0000-0002-8933-3965,

ORCID ID: 0000-0002-7753-6933,

ORCID ID: 0000-0002-3001-9955,

ORCID ID: 0000-0001-8837-2025

e-mail: surgery1@vnтu.edu.ua

Abstract. Aim of the study: To improve the results of surgical treatment of non-parasitic liver cysts by developing and improving methods of surgical intervention.

Materials and methods. When using laparoscopic methods of surgery, the average bed-day was $4.5 \pm 1.0$, postoperative complication occurred in 1 $(1.8 \%)$ case. In laparotomy methods, the average bed-day was $12.0 \pm 1.5$ and $2(6.3 \%)$ cases of postoperative complication, which confirms the benefits of miniinvasive treatment tactics. In the study of long-term results, relapse occurred in $3(2.9 \%)$ cases.

Results of the research. Asymptomatic course of the disease certainly complicated the tactics of treatment. Due to the availability of ultrasound examination $78(88.6 \%)$ with non-parasitic liver cysts and $13(92.9 \%)$ patients with polycystic ovary disease knew their diagnosis before the last visit to the hospital, of which $10(11.4 \%)$ patients with non-parasitic liver cysts and $4(3.9 \%)$ with polycystosis are forced to operate due to the development of life-threatening complications. Puncture-aspiration technique with the introduction of sclerosing solutions, which was performed in $23(26.1 \%)$ patients with nonparasitic liver cysts and the method of fenestration - $8(57.1 \%)$ patients with polycystic ovary syndrome, can most likely be attributed to palliative methods. In $2(2.3 \%)$ cases where there were doubts 
about the non-parasitic nature of cysts, enzyme-linked immunosorbent assay was performed and in $4(4.5 \%)$ patients with suspected malignancy were determined the absence of malignant genesis by tumor markers and morphological examination of the contents of diagnostic cyst puncture. When using laparoscopic methods of operation, the average bed-day was $4.5 \pm 1.0$, postoperative complication occurred in $1(1.8 \%)$ case, compared with laparotomic methods in which the average bed-day was $12.0 \pm 1,5$ and $2(6.3 \%)$ cases of postoperative complication, confirming the benefits of mini-invasive treatment tactics. In the study of long-term results, relapse occurred in $3(2.9 \%)$ cases.

\section{Conclusions:}

1. In order to prevent the development of dangerous complications of non-parasitic liver cysts and to diagnose them early, it is recommended to use radial examination methods and eliminate them with miniinvasive methods at an early stage of formation.

2. Puncture-aspiration methods of treatment of non-parasitic cysts with external drainage with periodic introduction of sclerosing solutions under ultrasound control are palliative, as evidenced by the presence of relapses (3.4\%). Their use is recommended for elderly patients with high comorbidity of concomitant pathology or as a preparatory stage for radical surgery.

3. The use of a mini-invasive method of fenestration of the cysts with deepithelialization of their membranes in polycystic liver is a surgery of choice, which allows to slow the development of hepatocellular insufficiency.

4. The combination of mini-invasive techniques with bipolar coagulation, or laser dissection, or welding electrocoagulation has led to a reduction in complications such as intraoperative bleeding and biliary leakage, and has made it possible to apply them not only to the cystectomy of large complications of cysts, but also to the treatment of complicated cysts.

5 . The use of the welding electrocoagulator EC$300 \mathrm{M}$ "Swarmed" in laparoscopic cystectomy led to a reduction in the duration of surgery and hospital stay by 2 times, the number of relapses - from 10 to $2.9 \%$.

Keywords: non-parasitic liver cysts, polycystic disease, mini-invasive methods.

Стаття надійшла в редакцію 13.05. 2020 p. 